\title{
Symulacja numeryczna i badania cykli cieplnych hartowania laserowego stali narzędziowej WCL
}

\author{
Numerical simulation and heat cycle examination \\ of WCL steel laser hardening.
}

\begin{abstract}
Streszczenie
W artykule tym zamieszczono wyniki badań przebiegu cykli cieplnych hartowania laserowego stali WCL za pomocą lasera diodowego ROFIN DL 020. Cykl cieplny mierzono na głębokościach 0,5, 1, 2 i 3 mm od powierzchni obrabianej, pomiary uzupełniono rozkładem powierzchniowym pól temperatur wykonanym kamerą termograficzną. Przeprowadzone symulacje numeryczne metodą MES w oprogramowaniu Sysweld pozwoliły na stwierdzenie wysokiej korelacji wyników symulacji z pomiarami i brak błędów związanych z zakłóceniami wprowadzonymi przez metody pomiarowe.
\end{abstract}

Słowa kluczowe: hartowanie laserowe; stal WCL; symulacje numeryczne; laser diodowy; Sysweld

\begin{abstract}
In this article results of heat cycle examination of WCL steel laser hardening with use of ROFIN DL 020 diode laser were presented. Heat cycle was measured on depths $0.5,1$, 2 and $3 \mathrm{~mm}$ from worked plane, measurements were supplemented with planar temperature field made with thermographic camera. Numerical FEM simulations of process carried with use of Sysweld software enabled determination of high convergence of simulation results with measurements and lack of errors introduced by measurements methods.
\end{abstract}

Keywords: laser hardening; WCL steel; numerical simulation; diode laser; Sysweld

\section{Wstęp}

Hartowanie laserowe jest procesem zmiany właściwości warstwy wierzchniej stopów metali na osnowie żelaza, mającym na celu zwiększenie odporności na ścieranie. Utwardzanie powierzchniowe stosuje się $\mathrm{w}$ produkcji narzędzi, krzywek, kół zębatych, wałów, w przemyśle samochodowym, przy produkcji turbin oraz w innych branżach [1]. Warstwom utwardzanym stawia się przede wszystkim wymagania co do twardości, jak i odporności na obciążenia dynamiczne. Hartowanie laserowe posiada szereg zalet w porównaniu do hartowania na wskroś. Przy hartowaniu jedynie cienkiej warstwy unikamy nadmiernych odkształceń hartowniczych oraz pęknięć z nimi związanych. Hartowanie laserowe jest to proces szybszy i oszczędny energetycznie w porównaniu z hartowaniem objętościowym. Bardzo wysokie prędkości nagrzewania i chłodzenia powodują występowanie drobnomartenzytycznej struktury o wysokiej twardości, a jednocześnie dostatecznej odporności na obciążenia dynamiczne pozwalając na stosowanie warstw hartowanych laserowo bez wyżarzania. Twardość wtórna w warstwach hartowanych laserowo zwykle jest wyższa niż w warstwach hartowanych konwencjonalnie, co powoduje, że także po wyżarzaniu odpuszczającym warstwy te posiadają własności lepsze niż w przypadku użycia konwencjonalnych metod hartowania [2]. Możliwość skupienia wiązki w znacznej odległości od głowicy pozwala na obróbkę miejsc niedostępnych dla metod takich jak hartowanie indukcyjne czy płomieniowe. Niewielka zmiana chropowatości powierzchni obrabianej, jak i brak oksydacji, przy użyciu odpowiedniej osłony, pozwalają na zmniejszenie ilości operacji po hartowaniu. Ponadto możliwa jest znacznie dokładniejsza kontrola ciepła wprowadzanego do elementu przez laser, jak i gęstości energii źródła laserowego, co w efekcie daje możliwość projektowania $w$ pewnych granicach własności różnych powierzchni obrabianego elementu. Wysokie prędkości chłodzenia pozwalają na zachowanie większej ilości pierwiastków stopowych w roztworze co może wspomagać odporność korozyjną takiej warstwy. Grubość warstwy hartowanej laserowo zawiera się zwykle w granicach od 0,25 mm do $0,75 \mathrm{~mm}$ [3].

Jednak proces hartowania laserowego nie jest łatwy w aplikacji. Potrzeba zachowania odpowiedniego czasu przebywania w temperaturach austenityzacji lub wysokiego

Mgr inż. Bernard Wyględacz; dr inż. Tomasz Kik; dr inż. Damian Janicki - Politechnika Śląska.

Autor korespondencyjny/Corresponding author: bernard.wygledacz@polsl.pl 
przegrzania, aby rozpuścić cały węgiel oraz składniki stopowe w osnowie, nie dopuszczając do stopienia materiału i zapewnienia szybkiego chłodzenia i niskiej temperatury końca chłodzenia przy użyciu jednego cyklu cieplnego sterowanego szeregiem parametrów wiązki laserowej oraz jej trajektorii [3]. Sytuacja ta ulega komplikacji, jeżeli obróbce poddawane są elementy o skomplikowanej geometrii, a sama obróbka zawiera wiele przejść częściowo się nakładających lub stykających. Z tego powodu przeprowadzono badania mające na celu określenie możliwości symulacji cykli cieplnych hartowania laserowego za pomocą lasera diodowego wysokiej mocy (HPDL) ROFIN DL 020 przy użyciu metody elementów skończonych w oprogramowaniu ESI Sysweld i określenie zbieżności symulacji z rzeczywistym procesem.

$Z$ wielu metod symulacji możliwych $w$ oprogramowaniu Sysweld wybrano symulację termo-metalurgiczną transient 3D, jako dającą możliwość przewidywania zmian pół temperatur w czasie procesu co pozwala określić objętościowy rozkład cykli cieplnych hartowania, a w efekcie optymalizować głębokość, kształt oraz własności warstwy hartowanej $[4,5]$.

\section{Badania}

Badaniom poddano okrągłe próbki ze stali narzędziowej WCL o składzie normowym podanym $\mathrm{w}$ tablicy I i wymiarach $\varnothing 80 \mathrm{~mm}$ i grubości $10 \mathrm{~mm}$. Materiał dostarczony został w stanie zmiękczonym i nie poddano go dodatkowym zabiegom obróbki cieplnej. Zabieg hartowania wykonano w osi próbki na powierzchni szlifowanej. Termoelementy typu $\mathrm{K}$ zostały przygrzane kondensatorowo w otworach o głębokości 7, 8, 9 oraz 9,5 mm rozmieszczonych co $10 \mathrm{~mm}$, a następnie druty termoparowe zostały zaizolowane elektrycznie w celu uniemożliwienia wzajemnego kontaktu drutów i próbki. Termoelementy podłączono poprzez przewody kompensacyjne z rejestratorem Agilent 34970A. Na stanowisku badawczym (rys. 1) zamontowano także kamerę termowizyjną FLIR a655sc. Badania termowizyjne wykonano z użyciem obiektywu $25^{\circ} \times 19^{\circ}$ przy rozdzielczości 640 na 480 punktów w zakresie $100-2000{ }^{\circ} \mathrm{C}$. W celu przeprowadzenia hartowania wykorzystano laser diodowy wysokiej mocy ROFIN DL 020 o wymiarach ogniska 6,8 x 1,8 mm. Następnie wykonano serię 10 prób hartowania laserowego z parametrami zawartymi w tablicy II. Po próbach wykonano makrozgłady ściegów hartowanych.

Tablica I. Skład stali WCL według PN-86 H-85021

Table I. Chemical composition of WCL steel acc. PN-86 H-85021

\begin{tabular}{|c|c|c|c|c|c|c|c|}
\hline \multicolumn{7}{|c|}{ Zawartość składników stopowych [\%] } \\
\hline $\mathrm{C}$ & $\mathrm{Mn}$ & $\mathrm{Si}$ & $\mathrm{P}$ & $\mathrm{S}$ & $\mathrm{Cr}$ & $\mathrm{Mo}$ & $\mathrm{V}$ \\
\hline $\begin{array}{c}0,32 \\
\div 0,42\end{array}$ & $\begin{array}{c}0,2 \\
\div 0,5\end{array}$ & $\begin{array}{c}0,8 \\
\div 1,2\end{array}$ & $\begin{array}{c}\max \\
0,030\end{array}$ & $\begin{array}{c}\max \\
0,030\end{array}$ & $\begin{array}{c}4,5 \\
\div 5,5\end{array}$ & $\begin{array}{c}1,2 \\
\div 1,5\end{array}$ & $\begin{array}{c}0,3 \\
\div 0,5\end{array}$ \\
\hline
\end{tabular}

Następnie przystąpiono do symulacji numerycznej. W celu przeprowadzenia symulacji zbudowano model składający się z 62477 węzłów i 28926 elementów 3D. Model widoczny na rysunku 2 posiada zagęszczenie siatki w obszarze hartowanym oraz węzły na głębokościach 0,5, 1, 2 i $3 \mathrm{~mm}$ co odpowiada umieszczeniu termoelementów w próbkach. Promieniowanie laserowe wnika w materiał na niewielką głębokość równą długości fali, więc proces hartowania laserowego można przyjąć jako nagrzewanie powierzchniowe. W celu symulacji wielomodowego rozkładu mocy lasera ROFIN DL 020 użyto zmodyfikowanego źródła na bazie podwójnej elipsoidy (źródła Goldaka). Podczas analizy wyników utworzono wykresy temperatur węzłów odpowiadających umieszczeniu termoelementów, powierzchniowe rozkłady temperatur odpowiadające zdjęciom kamery termowizyjnej i zdjęcia rozkładów temperatury na przekroju odpowiadające zdjęciom makroskopowym [5:7].

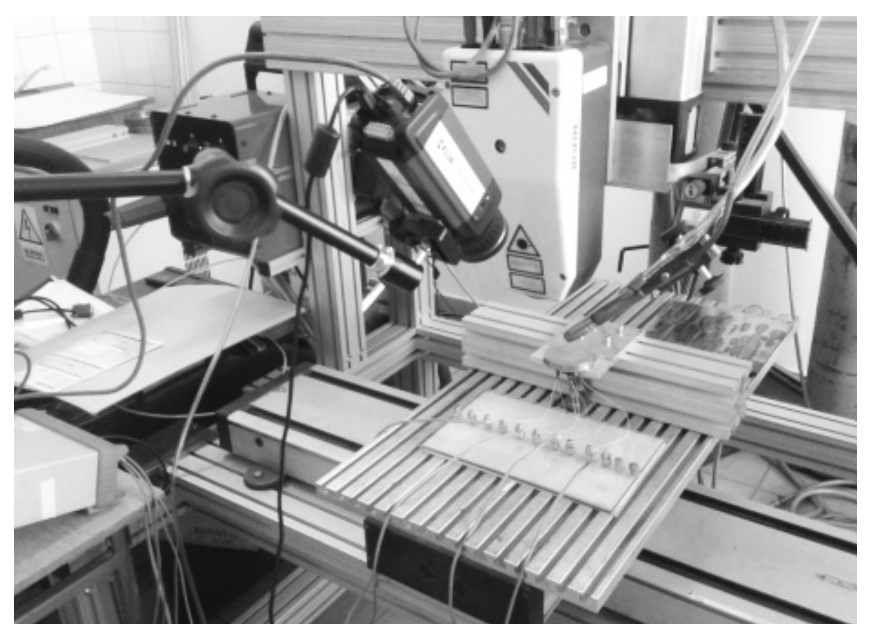

Rys. 1. Stanowisko do badania cykli cieplnych i rozkładu powierzchniowego temperatur hartowania laserowego

Fig. 1. Rig for heat cycle and planar temperature distribution examination in laser hardening

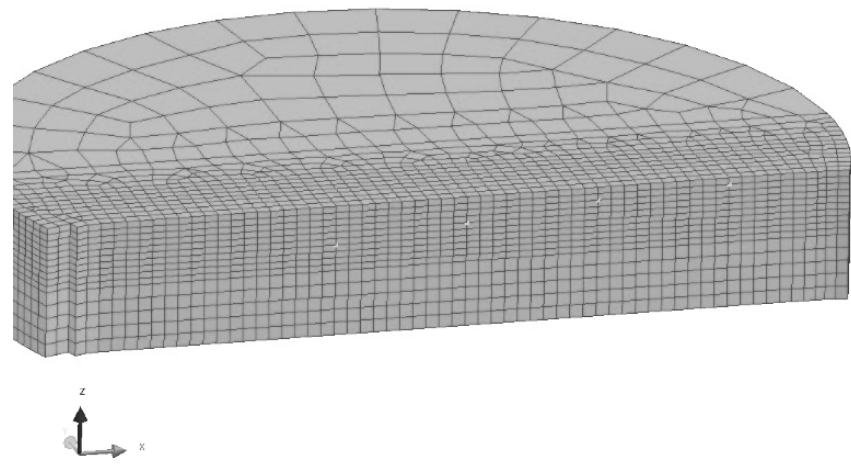

Rys. 2. Część modelu i umiejscowienie węzłów odpowiadających termoelementom

Fig. 2. Part of model and placement of nodes corresponding to thermocouples

Tablica II. Parametry hartowania laserem ROFIN DL 020

Table II. ROFIN DL 020 laser hardening parameters

\begin{tabular}{|c|c|c|c|c|c|c|c|c|c|c|}
\hline Ścieg & 1 & 2 & 3 & 4 & 5 & 6 & 7 & 8 & 9 & 10 \\
\hline Moc lasera [W] & 400 & 600 & 700 & 800 & 800 & 900 & 1000 & 1000 & 1100 & 1200 \\
\hline $\begin{array}{c}\text { Prędkość wiązki } \\
{[\mathrm{m} / \mathrm{min}]}\end{array}$ & 0,2 & 0,6 & 0,6 & 0,6 & 0,8 & 0,8 & 0,8 & 1 & 1 & 1 \\
\hline $\begin{array}{c}\text { Energia liniowa } \\
{[\mathrm{J} / \mathrm{cm}]}\end{array}$ & 1200 & 600 & 700 & 800 & 600 & 675 & 750 & 600 & 660 & 720 \\
\hline
\end{tabular}




\section{Wyniki i Analiza}

Na rysunku 3 przedstawiono przebiegi temperatur w wybranych punktach w czasie hartowania laserowego, jak i symulacji. Cykle cieplne dla termoelementu 4 i węzła 4 wykazują duże pokrycie. Jedynie obliczone cykle dla 3, 4, 5
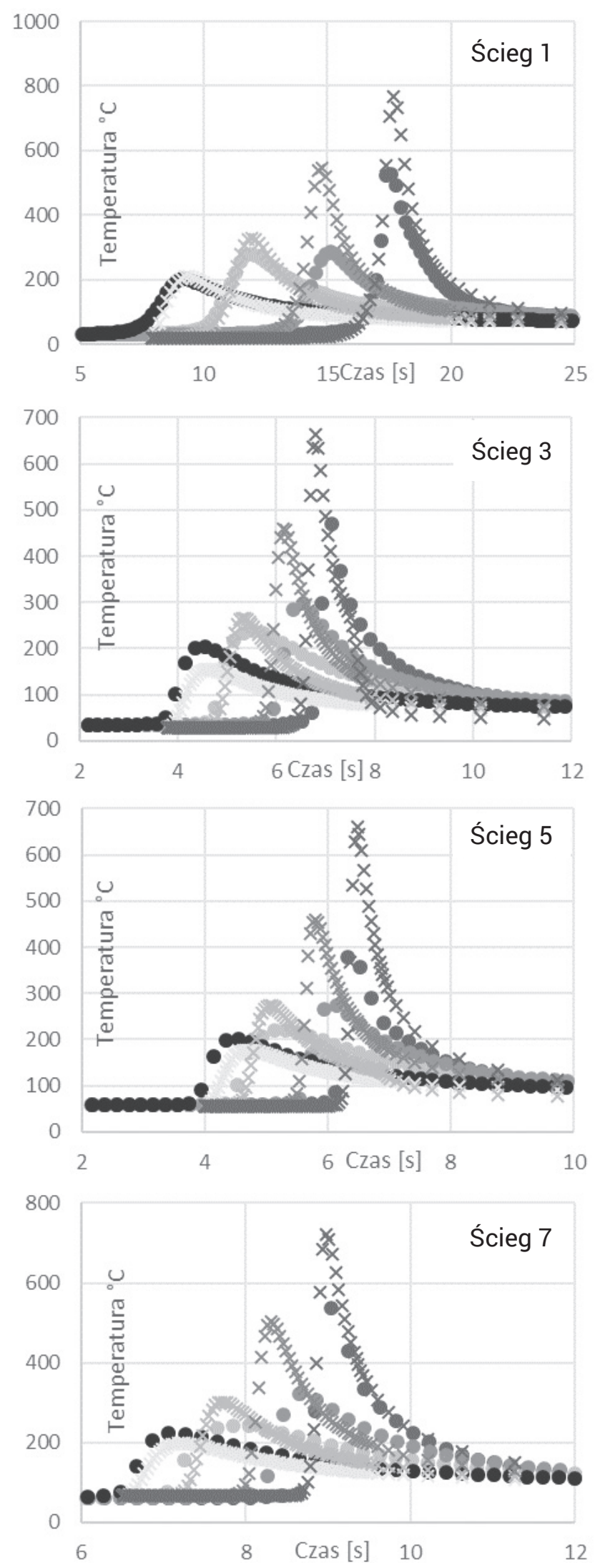

i 6 ściegu są nieznacznie niższe wartość w całości zakresu. Natomiast dla punktów 1, 2 i 3 wartości zmierzone znacznie różnią się od wyników symulacji. Symulacja wykazuje znacznie wyższe wartości, a błąd wynosi miejscami $50 \%$.
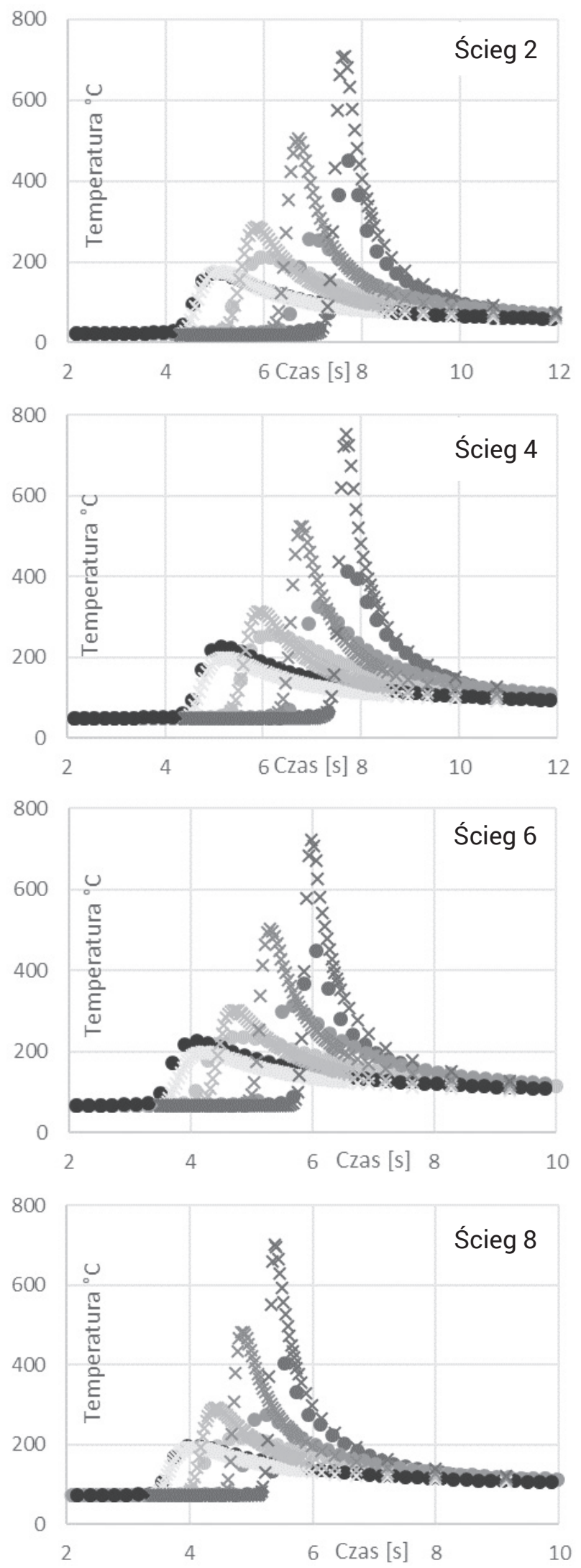

Termopara 1 Termopara 3 Termopara 2

Węzeł $4 \times$ Węzeł $3 \times$ Węzeł $2 \times$ Węzeł 1

Rys. 3. Przebieg zmierzonych oraz obliczonych cykli cieplnych

Fig. 3. Measured and calculated heat cycles 
$\mathrm{Na}$ rysunku 4 przedstawiono porównanie zdjęć termograficznych (w lewych kolumnach) z rozkładem pół temperatur uzyskanym w wyniku symulacji (w prawych kolumnach). Widoczna jest tu zależność kształtu pola temperatur od prędkości ruchu źródła po trajektorii. Zarówno na zdjęciach termograficznych, jak i w wynikach symulacji zwiększenie prędkości przemieszczania źródła powoduje wydłużenie pola o temp. $>100^{\circ} \mathrm{C}$. Na zdjęciach termograficznych widoczne jest znaczne zaszumienie spowodowane prawdopodobnie niejednorodnością współczynnika emisyjności.

Na rysunku 5 przedstawiono porównanie makrozgładów ściegów zahartowanych (naniesiono oznaczenie strefy zahartowanej) z rozkładem pól temperatur wyższych od $700{ }^{\circ} \mathrm{C}$ na przekroju przechodzącym przez środek źródła ciepła w czasie trwania procesu. We wszystkich ściegach widoczna jest duża korelacja pomiędzy kształtem i wymiarami strefy zahartowanej a polem osiągającym temperatury wyższe od $700^{\circ} \mathrm{C}$.

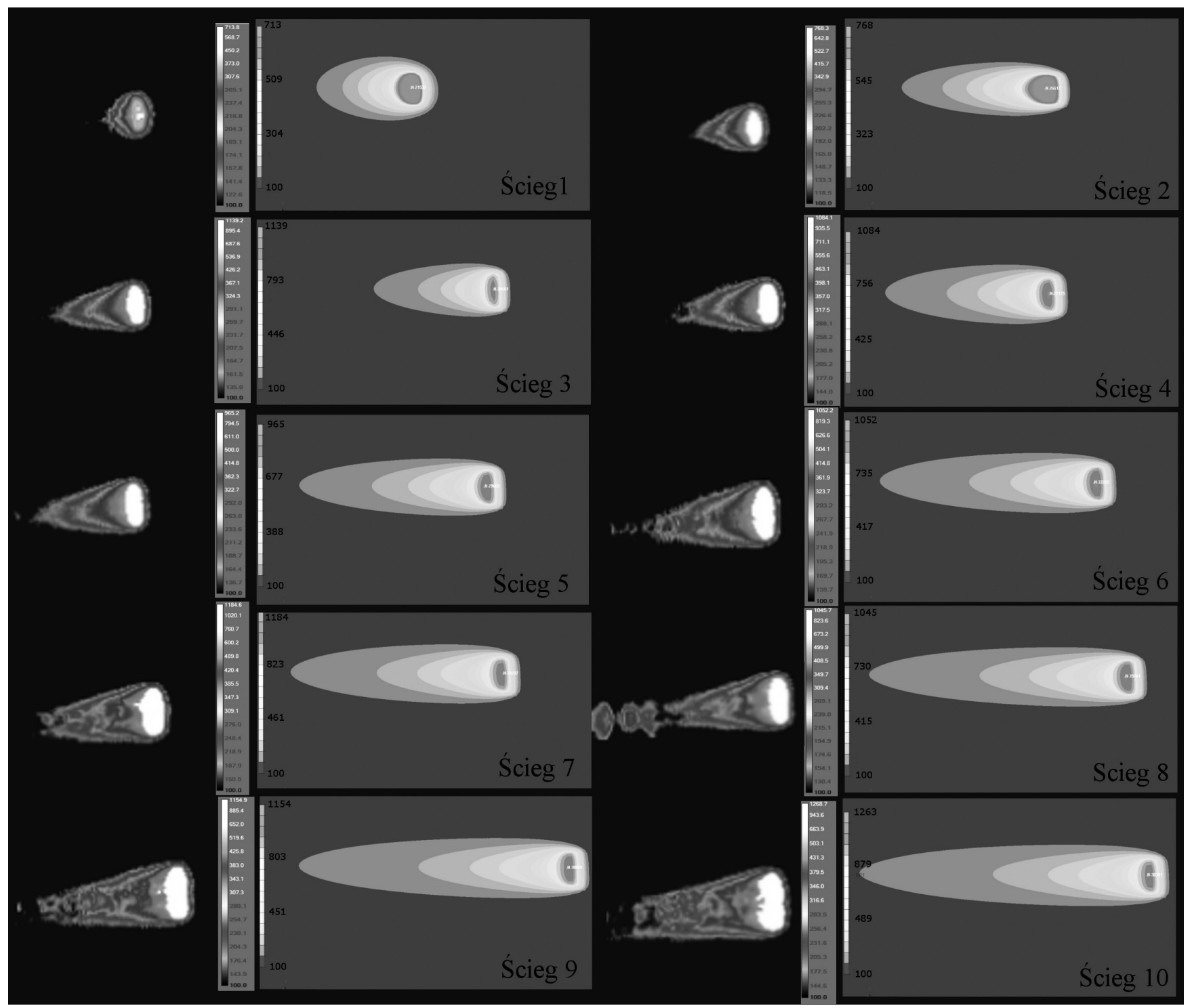

Rys. 4. Zdjęcia termograficzne oraz rozkład pól temperatury będący wynikiem symulacji

Fig. 4. Thermographic images and simulated temperature field distribution
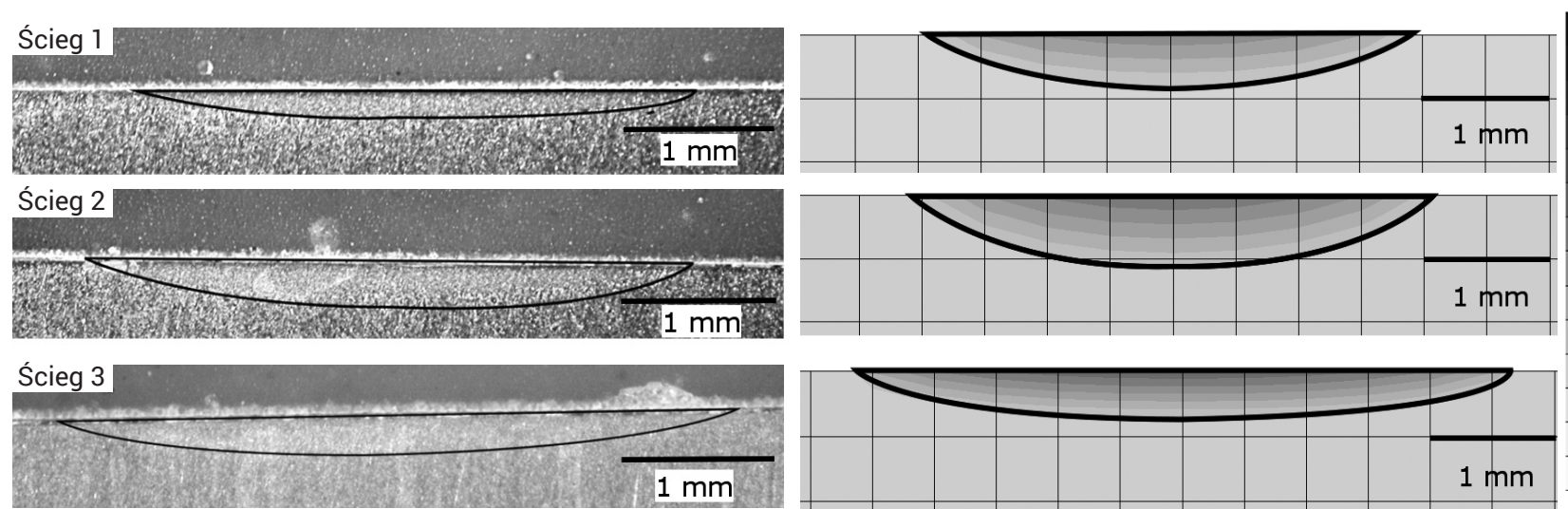

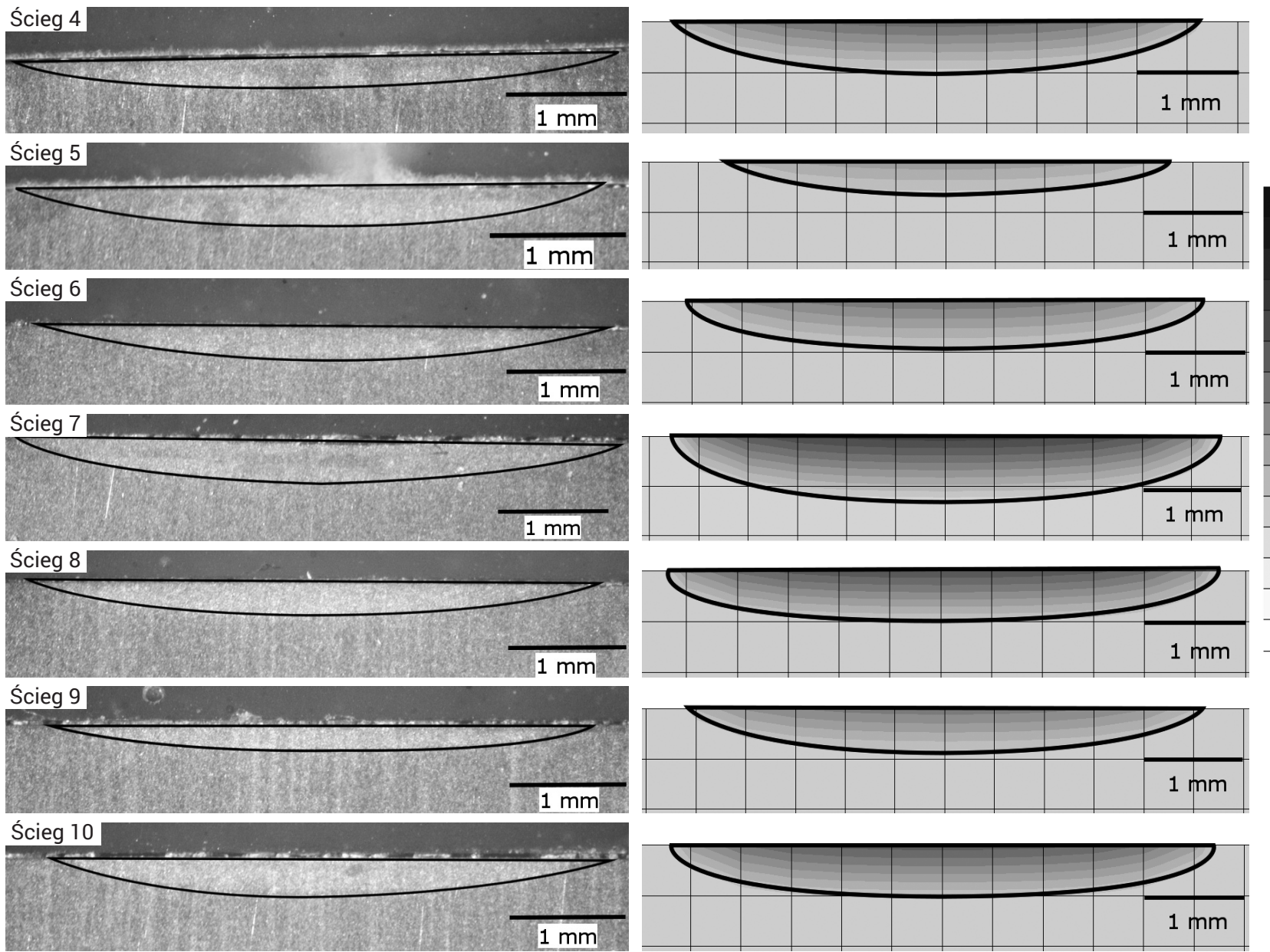

Rys. 5. Makrozgłady poprzeczne ściegów hartowanych (traw. Nital) i rozkład temperatur na przekroju przechodzącym przez punkt najwyższej temperatury w czasie hartowania

Fig. 5. Macroview of hardened seams cross-section (etching Nital) and temperature distribution on cross-section on through highest temperature during hardening

\section{Podsumowanie}

Wykresy cykli cieplnych nie wykazywały pełnego pokrycia, a rozbieżność pomiędzy symulacją a zarejestrowanymi parametrami rosła wraz ze zmniejszeniem głębokości pomiaru. Wysoka zgodność pomiędzy kształtem przekroi temperaturowych i zdjęć termograficznych pozwala sądzić, iż błąd ten mógł być spowodowany błędami pomiaru temperatury. Za przykład posłużyć może ścieg 10, w którym zarówno w symulacji, jak i na zgładzie stwierdzono, że pole zahartowane sięgać będzie ok. 0,6 mm w osi ściegu zahartowanego. W przypadku tym temperatura maksymalna osiągnięta w czasie symulacji na głębokości $0,5 \mathrm{~mm}$ wyniosła $813^{\circ} \mathrm{C}$, a maksymalna temperatura zmierzona termoelementem wyniosła jedynie $573{ }^{\circ} \mathrm{C}$. Błędu należałoby szukać tutaj w samej konstrukcji pomiaru. Przygrzany kulisty termoelement styka się ograniczoną powierzchnią z próbką w wywierconym kanale. Bezwładność cieplna termoelementu wraz z ograniczoną częstotliwością próbkowania powoduje zmniejszenie maksymalnej temperatury i zmniejszenie prędkości nagrzewania, a wywiercony kanał powoduje zmniejszenie prędkości chłodzenia obserwowanej na pomiarze cyklu cieplnego. Nie zaobserwowano korelacji pomiędzy energią liniową a kształtem i wymiarami strefy zahartowanej, co znajduje potwierdzenie w praktyce, gdzie do zoptymalizowania technologii hartowania laserowego potrzeba wielokrotnych prób oraz dużego doświadczenia w prowadzeniu procesu.

Podsumowując, numeryczna symulacja metodą elementów skończonych pozwala na przewidywanie z dużą dokładnością objętościowego rozkładu pól temperatur w czasie hartowania laserowego, co w połączeniu z wiedzą inżynierską pozwala na optymalizację kształtu i wymiarów strefy zahartowanej.

\section{Literatura}

[1] J. Dosset, G.E. Totten: ASM Handbook Volume 4A: Steel Heat Treating Fundamentals and Processes; ASM International, 2013.

[2] R. Villar, R. Colaco, A. Almeida: Laser Surface Treatment of Tool Steels, Laser Processings: Surface Treatment and Film Deposition 1996, pp. 453-478.

[3] M. Tobar, C. Alvarez, J. Amado, A. Ramil, E. Saavedra, A Yanez: Laser transformation hardening of a tool steel: Simulation-based parameter optimization and experimental results, Surface \& Coatings Technology 2002006 , pp. 6362-6367

[4] Welding simulation user guide, Sysweld manual ESI Group, 2016.
[5] T. Kik, M. Slovacek, J. Moravec, M. Vanek: Numerical Simulations of Heat Treatment Processes, Applied Mechanics and Materials, Vols. 809-810, pp. 799-804, 2015, DOI: 10.4028/www.scientific.net/AMM.809-810.799

[6] Bernard Wyględacz, Tomasz Kik, Symulacja numeryczna wpływu zmian warunków technologicznych na rozkład naprężeń i odkształceń wymiennika ciepła, Przegląd Spawalnictwa, 88, 2106

[7] W. Wu, N. Liang, C. Gan, G. Yu: Numerical investigation on laser transformation hardening with different temporal pulse shapes; Surface \& Coatings Technology 200 2006, pp. 2686-2694 